Contributions:

A Study design/planning

B Data collection/entry

C Data analysis/statistics

D Data interpretation

D Preparation of manuscript

E Preparation of manuscript

$G$ Funds collection

\title{
STAPES SURGERY FOR OTOSCLEROSIS: AUDIOMETRIC AND SELF-REPORTED HEARING OUTCOMES
}

\author{
Henryk Skarzynski ${ }^{1 A D E}$, Beata Dziendziel ${ }^{2 A B C D E F}$, Weronika Swierniak ${ }^{2 B F}$, \\ Elzbieta Gos ${ }^{2 C D E}$, Piotr H. Skarzynski²,3,4DEF
}

\author{
${ }^{1}$ Oto-Rhino-Laryngology Surgery Clinic, World Hearing Center, Institute of Physiology \\ and Pathology of Hearing, Warsaw/Kajetany, Poland \\ 2 Teleaudiology and Screening Department, World Hearing Center, Institute of Physiology \\ and Pathology of Hearing, Warsaw/Kajetany, Poland \\ ${ }^{3}$ Heart Failure and Cardiac Rehabilitation Department, $2^{\text {nd }}$ Faculty of Medicine, Medical \\ University of Warsaw, Warsaw, Poland \\ ${ }^{4}$ Institute of Sensory Organs, Warsaw/Kajetany, Poland
}

Corresponding author: Piotr H. Skarzynski, Mokra 17 Street, 05-830 Kajetany, e-mail: p.skarzynski@ifps.org.pl, tel. +48 223560366.

\begin{abstract}
Background. Stapes surgery is widely used to treat otosclerosis and its effectiveness is reported in audiometric terms - closure of the preoperative air-bone gap and improvement in air conduction thresholds. The objective of our study was to measure audiometric and self-assessed hearing changes in otosclerosis patients after stapes surgery. A secondary objective was to gauge the relationship between self-reported hearing and audiometric hearing thresholds.

Materials and Methods. This prospective study included 236 patients with otosclerosis who underwent primary stapedotomy. The Abbreviated Profile of Hearing Aid Benefit questionnaire (APHAB) was used to measure subjective hearing before surgery and 6 months postoperatively. Pure-tone audiometry was also conducted at the same observation periods.

Results. The air- and bone-conduction thresholds, as well as the air-bone gap, confirmed that there was a significant improvement in hearing. The difference between the pre- and postoperative APHAB Total score was 26.7 points and was statistically significant $(p<0.001)$. A weak correlation was found between the pre- and postoperative change of APHAB Total score and air conduction thresholds $(r h o=0.23 ; p<0.01)$ as well as between the change in the APHAB Total score and the size of the air-bone gap ( $r h o=0.19 ; p<0.05)$.
\end{abstract}

Conclusion. The results of the audiometric tests demonstrate the effectiveness of stapedotomy in improving the hearing of the majority of patients. However, audiometric results give limited information about the status of the patient's hearing. The patient's subjective perspective, together with the audiometric data, provide valuable information that can be helpful in clinical decision-making and counselling.

Key words: otosclerosis $\bullet$ stapedotomy $\bullet$ audiometric outcomes $\bullet$ self-reported hearing outcomes $\bullet$ patient's perspective $\bullet$ APHAB questionnaire

\section{CIRUGÍA DE ESTRIBO EN LA OTOSCLEROSIS: RESULTADOS AUDIOMÉTRICOS Y RESULTADOS AUDITIVOS AUTOINFORMADOS}

\section{Resumen}

Introducción: La cirugía de estribo es un método ampliamente utilizado en el tratamiento de la otosclerosis y su efectividad se informa en relación con los resultados de las pruebas audiométricas - cierre de la reserva coclear preoperatoria y mejora de los umbrales de conducción aérea. El objetivo del estudio fue evaluar el cambio en la audición en relación con los resultados de las pruebas audiométricas y los cuestionarios de autoinforme en el grupo de pacientes con otosclerosis sometidos a cirugía de estribo. El segundo objetivo fue evaluar la relación entre la audición subjetiva informada por los pacientes y los umbrales auditivos audiométricos.

Materiales y Métodos: El estudio prospectivo incluyó un grupo de 236 pacientes con otosclerosis que se sometieron a una estapedotomía. Se evaluó la audición subjetiva antes y seis meses después de la cirugía usando el cuestionario Abbreviated Profile of Hearing Aid Benefit (APHAB). La prueba de audiometría tonal se realizó durante los mismos períodos de observación.

Resultados: Los resultados obtenidos para los umbrales de conducción aérea y ósea, así como la reserva coclear, confirmaron una mejora significativa en la audición. La diferencia entre los resultados del cuestionario APHAB total preoperatorio y postoperatorio fue de 26,7 puntos y fue estadísticamente significativa $(\mathrm{p}<0,001)$. Hubo una débil correlación entre el cambio postoperatorio en los resultados totales del cuestionario APHAB y los umbrales de conducción aérea (rho $=0,23 ; \mathrm{p}<0,01)$ así como entre el cambio en los resultados totales del cuestionario $\mathrm{APHAB}$ y el tamaño de reserva coclear ( $r h o=0,19 ; \mathrm{p}<0,05)$.

Conclusiones: Los resultados audiométricos obtenidos confirmaron la mejora de la audición en la mayoría de los pacientes sometidos a estapedotomía. Sin embargo, los resultados audiométricos proporcionan información limitada sobre la condición auditiva informada por los pacientes. La evaluación subjetiva de los pacientes, además de los resultados de las pruebas audiométricas, proporciona información valiosa que puede ser útil en la toma de decisiones y el proceso de consulta.

Palabras clave: otosclerosis • estapedotomía • resultados audiométricos • resultados auditivos autoinformados • perspectiva del paciente • cuestionario APHAB 


\title{
ХИРУРГИЧЕСКАЯ ОПЕРАЦИЯ НА СТРЕМЕЧКЕ ПРИ ОТОСКЛЕРОЗЕ: АУДИОМЕТРИЧЕСКИЕ И СУБЪЕКТИВНЫЕ РЕЗУЛЬТАТЫ ОЦЕНКИ СЛУХА
}

\begin{abstract}
Аннотация
Введение: Хирургическая операция настремечке является повсеместно используемым методом лечения отосклероза, а его эффективность подкрепляется результатами аудиометрических исследований: закрытие предоперационного костно-воздушного разрыва, а также улучшение порогов воздушной проводимости. Целью исследования являлась оценка изменений слуха на основании результатов аудиометрических исследований, а также самозаполняемых опросников, заполненных группой пациентов с отосклерозом после проведенной хирургической операции на стремечке. Второй целью исследования являлась оценка коррелации субъективного слуха пациентов и аудиометрических порогов слуха.
\end{abstract}

Материалы и методы: Проспективные исследования прошла группа 236 пациентов с отосклерозом, которым была проведенастапедопластика. Субъективный слух до операции и спустя 6 месяцев после операции был оценен с помощью анкеты «Abbreviated Profile of Hearing Aid Benefit» (АРНАВ). Тональная аудиометрия была проиведена в те же периоды исследования.

Результаты: Полученные результаты для порогов воздушной и костной проводимости, а также костно-воздушный разрыв подтвердили существенное улучшение слуха. Разница между дооперационными и послеоперационными итоговыми результатами анкеты АРНАВ составила 26,7 пунктов и была статистически значимой $(p<0,001)$. Была представлена слабая корреляция между послеоперационными изменениями итоговых результатов анкеты АРНАВ и порогами воздушной проводимости $(r h o=0,23 ; p<0,01)$, а также между изменениями итоговых результатов анкеты АРНАВ и величиной костно-воздушного разрыва $(r h o=0,19 ; p<0,05)$.

Подведение итогов: Полученные результаты аудиометрических исследований подтвердили улучшение слуха у большинства пациентов, которым была проведена стапедопластика. Однако, результаты аудиометрических обследований предоставляют ограниченную информацию о состоянии слуха по мнению пациентов. Субъективная оценка пациентов наряду с результатами аудиометрических исследований предоставляет ценную информацию, которая может быть полезной в процессе принятия решений и консультаций.

Ключевые слова: отосклероз • стапедопластика • результаты аудиометрических исследований • субъективные результаты оценки слуха • перспектива пациента • анкета АРНАВ

\section{CHIRURGIA STRZEMIACCZKA W OTOSKLEROZIE: AUDIOMETRYCZNE I SAMOOPISOWE WYNIKI SŁUCHOWE}

\section{Streszczenie}

Wprowadzenie: Chirurgia strzemiączka jest powszechnie stosowaną metodą w leczeniu otosklerozy, a jej efektywność raportowana jest w odniesieniu do wyników badań audiometrycznych - zamknięcia przedoperacyjnej rezerwy ślimakowej oraz poprawy progów przewodnictwa powietrznego. Celem badania była ocena zmiany w słyszeniu w odniesieniu do wyników badań audiometrycznych oraz kwestionariuszy samoopisowych w grupie pacjentów z otosklerozą poddanych chirurgii strzemiączka. Drugim celem była ocena związku pomiędzy subiektywnym słyszeniem zgłaszanym przez pacjentów, a audiometrycznymi progami słyszenia.

Materiały i Metody: Prospektywnymi badaniami objęto grupę 236 pacjentów z otosklerozą, poddanych stapedotomii. Subiektywne słyszenie przed oraz 6 miesięcy po operacji oceniono za pomoca kwestionariusza Abbreviated Profile of Hearing Aid Benefit (APHAB). Badanie audiometrii tonalnej wykonano dla tych samych okresów obserwacji.

Wyniki: Uzyskane wyniki dla progów przewodnictwa powietrznego i kostnego, jak również rezerwy ślimakowej potwierdziły istotną poprawę słyszenia. Różnica pomiędzy przed i pooperacyjnymi całkowitymi wynikami kwestionariusza APHAB wyniosła 26,7 punktów i była istotna statystycznie $(p<0,001)$. Wykazano słabą korelację pomiędzy pooperacyjną zmianą całkowitych wyników kwestionariusza APHAB, a progami przewodnictwa powietrznego $(r h o=0,23 ; p<0,01)$, jak również pomiędzy zmianą całkowitych wyników kwestionariusza APHAB, a wielkością rezerwy ślimakowej $(r h o=0,19 ; p<0,05)$

Podsumowanie: Uzyskane wyniki badań audiometrycznych potwierdziły poprawę słyszenia u większości pacjentów poddanych stapedotomii. Jakkolwiek, wyniki audiometryczne dostarczają ograniczone informacje na temat stanu słyszenia zgłaszanego przez pacjentów. Subiektywna ocena pacjentów, obok wyników badań audiometrycznych, dostarcza cennych informacji, które mogą być pomocne w procesie podejmowania decyzji i konsultacji.

Słowa kluczowe: otoskleroza $\bullet$ stapedotomia $\bullet$ wyniki audiometryczne $\bullet$ samoopisowe wyniki słuchu $\bullet$ perspektywa pacjenta $\bullet$ kwestionariusz $\mathrm{APHAB}$

\section{Introduction}

Otosclerosis is a common form of adult-onset hearing impairment, typically characterized by disordered bone development. Otosclerosis has traditionally been regarded as a middle-ear disease but the inner ear can also be affected, with mixed or pure sensorineural hearing loss, tinnitus, and sometimes vertigo (1-3). The reasons for the formation and development of otosclerosis are not fully understood and so the disease remains incurable (4). Based on the Swedish Quality Register for otosclerosis, Ströbäck et al. estimate that in a population of 10 million, an average of 450 otosclerosis ears are treated annually, with the number varying from 380 to 580 per year over the last 10 years (5).

For more than 50 years, treatment of this form of hearing loss relied first on stapedectomy and more recently on stapedotomy (6). High rates of success of otosclerosis treatment using stapes surgery, with long-term stable outcomes, have been demonstrated repeatedly in many 
studies $(7,8)$. Pure-tone audiometry is the "gold standard" in assessing the effectiveness of stapes surgery. Results are reported in audiometric terms: closure of the preoperative air-bone gap and improvement in air conduction thresholds (8). However, the results of audiometric tests fail to tell us about how improvement of a patient's air conduction thresholds or closure of the air-bone gap translate into better subjective hearing. In the same way, the negative effects of progressive hearing loss caused by otosclerosis - such as impairment of the patient's physical, cognitive, behavioural, or social function - are difficult to assess (9-11). Problems with hearing loss can also force changes in the patient's lifestyle and give rise to constant emotional tension (12).

Evaluation of subjective hearing is possible using self-reported questionnaires (13) that have good psychometric characteristics in terms of reliability and validity. Self-reported tools can provide unique insights into the consequences of hearing loss which are unobtainable using conventional objective clinical assessments (14). Although there are a few scientific reports from medical centers around the world which have been published on hearing change after stapes surgery from the patient's point of view, to the best of our knowledge the results of similar prospective studies conducted among Polish patients have not so far been reported $(9,10,15-18)$.

To fill this knowledge gap, the aim of our study was to measure audiometric and self-assessed hearing change in otosclerosis patients after stapes surgery. A secondary objective was to gauge the relationship between self-reported hearing and audiometric hearing thresholds.

\section{Materials and method}

\section{Patients and study design}

Consecutive patients were enrolled in this prospective study in a tertiary referral center. Conducting audiometric measurements and making self-assessments of hearing changes in otosclerosis patients after undergoing stapes surgery is part of a larger study being carried out in our center on the multidimensional benefits of stapes surgery. The study was designed and conducted according to the Declaration of Helsinki and the study protocol was reviewed and approved by the institutional review board. Every patient gave written informed consent to participate in the study.

The main eligibility inclusion criteria were:

- age $\geq 18$ years

- preoperative audiological diagnosis indicative of otosclerosis (based on pure-tone audiometry, impedance audiometry, and anamnesis)

- no previous procedure of stapes surgery

- no contraindication to taking part in a questionnaire study.

\section{Exclusion criteria were:}

- no confirmed otosclerosis intraoperatively

- different surgical procedure other than stapedotomy
- surgery on the second ear during the postoperative interval

- resignation from the study by the patient.

\section{Audiometric testing}

Hearing thresholds for air conduction were determined at frequencies of $0.125,0.25,0.5,1,2,4$, and $8 \mathrm{kHz}$ at the preoperative period ( 1 day before surgery) and at the 6 month follow-up. The pure tone average $\left(\mathrm{PTA}_{4}\right)$ for air conduction (AC) and bone conduction (BC) was determined at $0.5,1,2$, and $4 \mathrm{kHz}$. Changes at these frequencies were calculated by subtracting postoperative values from the preoperative ones. The air-bone gap (ABG) was calculated as the difference between average $\mathrm{AC}$ and $\mathrm{BC}$ thresholds. Based on the preoperative $\mathrm{PTA}_{4}$, grades of hearing impairment according to the World Health Organization (WHO) guidelines were determined (19). Based on these grades, the patients were divided into three groups: slight (PTA 26-40 dB HL), moderate (PTA 41-60 dB HL), and severe-profound (PTA $>61 \mathrm{~dB} \mathrm{HL}$ ) hearing impairment.

\section{Self-reported hearing}

The Abbreviated Profile of Hearing Aid Benefit (APHAB) is a self-reported tool used to quantify the impact of a hearing problem on an individual's daily life in which the subject reports the degree of difficulty they are having with communication and in perceiving environmental sounds (20). APHAB is the most widely used hearing-specific questionnaire among Polish audiology patients. APHAB measures both unaided (without amplification) and aided (with amplification) performance. The APHAB comprises 24 items divided into four subscales: ease of communication (EC), background noise (BN), reverberation (RV), and aversiveness (AV). The APHAB Total score sums the subscales $\mathrm{EC}, \mathrm{BN}$, and $\mathrm{RV}$ and reflects the degree of difficulty with everyday speech communication in different acoustic situations. The AV scale considers negative reactions to environmental sounds. Each item has a 7-point response scale from 'always' to 'never'. Higher scores reflect greater difficulty caused by hearing loss. We deemed that the questionnaire was filled in adequately if the patient answered at least 20 of the 24 items (83\%). According to the study protocol, the APHAB was filled in three times: before, and 3 and 6 months after surgery. However, for this work we used only the preoperative results and those 6 months after surgery. The change in hearing was calculated by subtracting the postoperative result from the preoperative result; the bigger the difference, the greater the improvement in hearing.

\section{Stapedotomy technique}

All patients underwent surgery under general anesthesia and were operated on by two senior surgeons of our department. A Rosen incision was performed on the posterior wall of the external meatus and the chorda tympani identified. A small enlargement of the view was then performed with a 0.8 or $1.0 \mathrm{~mm}$ diameter low-speed drill. The mobility of the ossicular chain was then inspected. The incudo-stapedial joint was disarticulated with a small hook, the stapedial tendon was cut with delicate scissors, and the posterior branch of the stapes removed. A small 
fenestra was made in the stapes footplate with a low-speed drill ( $0.6 \mathrm{~mm}$ diameter) and a Skarzynski piston prosthesis (Kurz GmbH, Dusslingen, Germany) was inserted and crimped over the long process of the incus. A blood clot was used to seal the fenestra.

\section{Statistical analysis}

A $t$-test for paired samples was used to analyse APHAB results pre- and postoperatively. Due to violation of normality, a Wilcoxon signed-rank test was used for the analysis of pure-tone results pre- and postoperatively. Spearman rank correlation coefficients were calculated to assess the relationship between audiometry data and $\mathrm{APHAB}$ results. Criteria provided by Fackrell et al. were used to evaluate the strength of the correlation: coefficients higher than 0.8 were classified as extremely strong, those between 0.6 and 0.79 as strong, between 0.3 and 0.59 as moderate, and below 0.3 as weak (21). The statistically significant level was set at $p<0.05$. For statistical analysis, IBM SPSS Statistics v. 24 software was used.

\section{Results}

Between April and August 2017, there were 389 adults patients with otosclerosis who underwent primary stapedotomy in our center. We excluded 19 patients who had undergone operation of the second ear and 24 patients who refused to further participate in the study during postoperative follow-up. Twenty-two patients were excluded from analysis due to incomplete questionnaires. We assumed that the subjective change in hearing after surgery

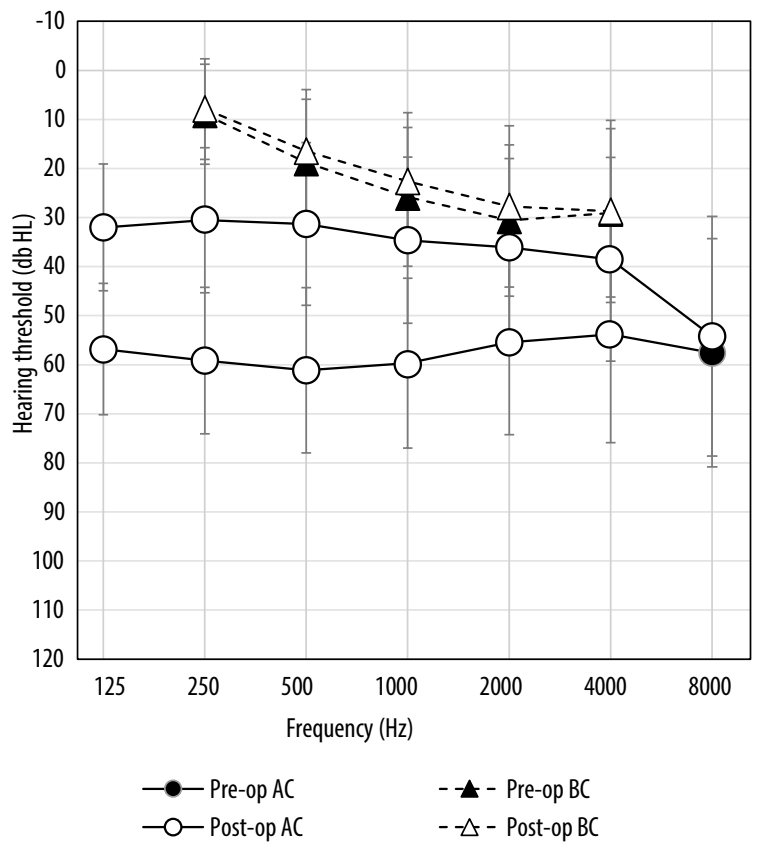

Abbreviations: Pre-op AC, pre-operative air conduction threshold; Post-op AC, post-operative air conduction threshold; Pre-op BC, pre-operative bone conduction threshold; Post-op BC, post-operative bone conduction threshold; error bars show standard deviations

Figure 1. Pre- and postoperative air and bone conduction thresholds could only be reliably assessed by patients who did not use a hearing aid in the operated ear prior to surgery. Therefore, 72 users of hearing aids were excluded from the analysis. Of the remaining 252 patients, 57 (23\%) of them did not attend a postoperative medical visit, so questionnaires were posted to these patients with a response rate of $72 \%$. This meant that, finally, results of the questionnaire could be analysed for 236 patients ( 174 women and 62 men). Their ages ranged from 21 to 75 years (mean, $M=47.8$, standard deviation, $S D=10.9$ years). The audiometric results could be analysed in 195 patients.

\section{Audiometric outcomes}

In the group of 195 patients, the preoperative audiometric results for the ear qualified for surgery confirmed mixed hearing loss in 144 ears and conductive hearing loss in 51. The duration of hearing loss (understood as the time from diagnosis of hearing loss to surgery) was on average $M=9.6, S D=7.2$ years. Preoperatively, bilateral hearing loss was diagnosed in 162 patients and unilateral in 33 . The pre- and postoperative pure-tone average $\mathrm{AC}$ and $\mathrm{BC}$ thresholds at all tested frequencies are shown in Figure 1.

The size of the ABG before surgery was $M=31.5$, $S D=10.2 \mathrm{~dB}$, and after stapedotomy $M=11.1, S D=6.3 \mathrm{~dB}$. The difference between the pre- and postoperative ABG was $11.2, S D=7.1 \mathrm{~dB}$, and was statistically significant $(Z=-11.9 ; p<0.001)$. The ABG was closed within $10 \mathrm{~dB}$ in 145 cases (74\%), and within $20 \mathrm{~dB}$ in 184 cases (96\%).

The average values of $\mathrm{AC}$ and $\mathrm{BC}$ thresholds and the size of the $A B G$, including the classification of hearing impairment according to the $\mathrm{WHO}$, are shown in Table 1.

In the group of patients with slight hearing impairment, the difference between the pre- and postoperative AC thresholds was $10.6 \mathrm{~dB}$, and was statistically significant $(Z=-4.29 ; p<0.001)$; the difference between the pre- and postoperative $\mathrm{BC}$ was $1.5 \mathrm{~dB}$ and was statistically significant $(Z=-1.98 ; p<0.05)$; the difference between the preand postoperative $\mathrm{ABG}$ was $9.1 \mathrm{~dB}$ and was statistically significant $(Z=-4.39 ; p<0.001)$. In the group of patients with moderate hearing impairment, the difference between the pre- and postoperative $\mathrm{AC}$ thresholds was $21.9 \mathrm{~dB}$, and was statistically significant $(Z=-8.50 ; p<0.001)$; the difference between the pre- and postoperative BC was $2.5 \mathrm{~dB}$ and was statistically significant $(Z=-3.85 ; p<0.001)$; the difference between the pre- and postoperative ABG was $19.4 \mathrm{~dB}$ and was statistically significant $(Z=-8.43 ; p<0.001)$. In the group of patients with severe-profound hearing impairment, the difference between the pre- and postoperative AC thresholds was $27.4 \mathrm{~dB}$, and was statistically significant $(Z=-7.38 ; p<0.001)$; the difference between the pre- and postoperative $\mathrm{BC}$ was $2.0 \mathrm{~dB}$ and was statistically significant $(Z=-2.28 ; p>0.05)$; the difference between the pre- and postoperative ABG was $25.5 \mathrm{~dB}$ and was statistically significant $(Z=-7.34 ; p<0.001)$.

\section{Self-reported hearing outcomes}

In the group of 236 patients, the average results of subscales of the APHAB questionnaire preoperatively, and at 6 months after stapedotomy, are shown in Figure 2. 
Table 1. Average thresholds for air- and bone-conduction and air-bone gap preoperatively, and at 6 months after stapedotomy. Sample size divided into three groups on the basis of classification of hearing impairment according to the World Health Organization

\begin{tabular}{|c|c|c|c|c|c|c|c|c|c|}
\hline Hearing impairment & $\mathrm{PTA}_{4}$ & Observation & Min & $\operatorname{Max}$ & $M$ & SD & Q1 & $\mathrm{Me}$ & Q3 \\
\hline \multirow{6}{*}{$\begin{array}{l}\text { Slight } \\
(n=27)\end{array}$} & \multirow{2}{*}{$A C$} & Pre-op & 26.3 & 40.0 & 35.2 & 4.8 & 32.5 & 37.5 & 38.8 \\
\hline & & Post-op & 5.0 & 42.5 & 24.6 & 8.5 & 18.8 & 23.8 & 28.8 \\
\hline & \multirow{2}{*}{$\mathrm{BC}$} & Pre-op & 6.3 & 26.6 & 15.1 & 5.2 & 11.3 & 13.8 & 17.5 \\
\hline & & Post-op & 0.0 & 26.3 & 13.6 & 6.2 & 10.0 & 12.5 & 17.5 \\
\hline & \multirow{2}{*}{$A B G$} & Pre-op & 11.3 & 27.6 & 20.1 & 4.9 & 15.0 & 20.0 & 23.8 \\
\hline & & Post-op & 3.8 & 28.8 & 11.0 & 5.9 & 8.8 & 10.0 & 11.3 \\
\hline \multirow{6}{*}{$\begin{array}{l}\text { Moderate } \\
(n=96)\end{array}$} & \multirow{2}{*}{$\mathrm{AC}$} & Pre-op & 41.3 & 60.0 & 51.0 & 5.3 & 45.3 & 52.5 & 55.0 \\
\hline & & Post-op & 15.0 & 57.5 & 29.1 & 8.5 & 23.8 & 28.8 & 32.5 \\
\hline & \multirow{2}{*}{$\mathrm{BC}$} & Pre-op & 6.3 & 43.8 & 21.5 & 8.9 & 16.3 & 20.0 & 25.0 \\
\hline & & Post-op & 5.0 & 48.8 & 19.0 & 8.1 & 12.8 & 18.8 & 22.5 \\
\hline & \multirow{2}{*}{$A B G$} & Pre-op & 9.8 & 46.3 & 29.5 & 8.7 & 23.8 & 30.0 & 35.6 \\
\hline & & Post-op & 2.5 & 27.5 & 10.1 & 4.8 & 7.5 & 8.8 & 10.0 \\
\hline \multirow{6}{*}{$\begin{array}{l}\text { Severe- } \\
\text { profound } \\
(n=72)\end{array}$} & \multirow{2}{*}{$A C$} & Pre-op & 61.3 & 117.5 & 74.5 & 13.7 & 63.8 & 71.3 & 78.8 \\
\hline & & Post-op & 17.5 & 108.8 & 47.1 & 19.9 & 35.5 & 43.8 & 50.0 \\
\hline & \multirow{2}{*}{$\mathrm{BC}$} & Pre-op & 15.0 & 72.5 & 36.3 & 13.0 & 27.5 & 33.8 & 42.5 \\
\hline & & Post-op & 6.3 & 76.3 & 34.3 & 15.3 & 23.8 & 32.5 & 40.9 \\
\hline & \multirow{2}{*}{$A B G$} & Pre-op & 16.3 & 62.5 & 38.3 & 8.6 & 32.5 & 38.8 & 43.8 \\
\hline & & Post-op & 1.3 & 52.5 & 12.8 & 9.5 & 8.8 & 10.0 & 15.9 \\
\hline
\end{tabular}

Abbreviations: PTA4, pure tone average; AC, air conduction; BC, bone conduction; ABG, air bone gap; Min, minimum; Max, maximum; M, mean; SD, standard deviation; Q1, first quartile; Me, median; Q3, third quartile

Statistical analysis showed a significant reduction in the degree of difficulty with everyday speech communication in different acoustic situations. The difference between the pre- and postoperative APHAB Total score was 26.7 points and was statistically significant $(t=20.29 ; p<0.001)$. A statistically significant reduction in hearing problems was observed in the EC, BN, and RV subscales of the APHAB questionnaire. The difference between the pre- and postoperative AV subscale increased by 2.5 points, reflecting an increase in the patient's negative reaction to loud sounds after surgery, but the difference was not statistically significant $(t=-1.52 ; p>0.05)$.

The average results of hearing for subscales of APHAB before and after stapedotomy, including the classification of hearing impairment according to WHO, are shown in Table 2.

For each group of patients differing in hearing impairment, we observed a significant, subjective reduction of the degree of difficulty in hearing after stapedotomy. The smallest statistically significant difference $(t=4.9 ; p<0.001)$ between the pre- and postoperative APHAB Total score $(M=14.3$; $S D=15.8$ ) was observed in the group of patients with slight hearing impairment. The largest statistically significant $(t=$ $17.6 ; p<0.001)$ change between the pre- and postoperative APHAB Total score $(M=31.6 ; S D=19.8)$ was reported in the group of patients with moderate hearing impairment. In the group of patients with severe-profound hearing impairment the difference between the pre- and postoperative APHAB Total score was $M=24.0, S D=20.0$ and was also statistically significant $(t=11.0 ; p<0.001)$.

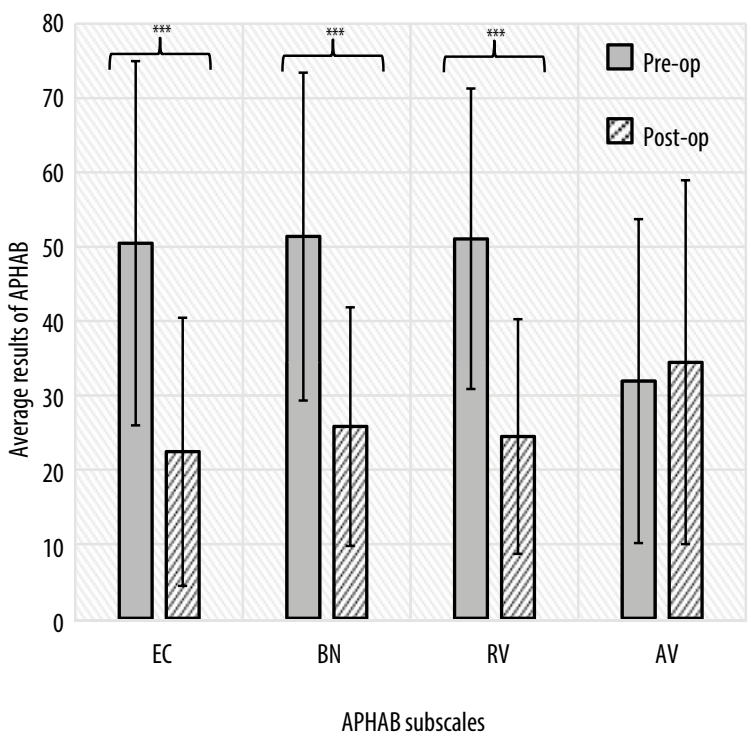

Abbreviations: $\mathrm{EC}$, ease of communication; $\mathrm{BN}$, background noise; RV, reverberation; $\mathrm{AV}$, aversiveness; ${ }^{* * *} p<0.001$;

Figure 2. Average results of subscales of the APHAB questionnaire preoperatively (grey bars) and at 6 months after stapedotomy (cross-hatched bars). Error bars show standard deviation. 
Table 2. Average results of subscales of the APHAB questionnaire before and 6 months after surgery. Sample size divided into three groups of hearing impairment on the basis of WHO classification

\begin{tabular}{|c|c|c|c|c|c|c|c|c|c|}
\hline Hearing impairment & APHAB subscale & Observation & Min & Max & $M$ & SD & Q1 & $\mathrm{Me}$ & Q3 \\
\hline \multirow{8}{*}{$\begin{array}{l}\text { Slight } \\
(n=27)\end{array}$} & \multirow{2}{*}{ EC } & Pre-op & 6.8 & 78.7 & 37.3 & 20.6 & 16.7 & 35.3 & 56.1 \\
\hline & & Post-op & 4.7 & 45.8 & 21.4 & 13.1 & 8.3 & 18.8 & 32.2 \\
\hline & \multirow{2}{*}{ BN } & Pre-op & 8.7 & 89.0 & 41.7 & 20.9 & 25.0 & 41.7 & 52.9 \\
\hline & & Post-op & 4.7 & 56.2 & 28.5 & 15.8 & 20.4 & 24.8 & 43.6 \\
\hline & \multirow{2}{*}{ RV } & Pre-op & 6.5 & 70.7 & 39.4 & 17.4 & 24.9 & 39.3 & 50.9 \\
\hline & & Post-op & 2.8 & 52.0 & 25.3 & 15.9 & 9.2 & 26.8 & 35.3 \\
\hline & \multirow{2}{*}{ AV } & Pre-op & 1.0 & 81.0 & 30.6 & 23.2 & 10.2 & 30.8 & 45.7 \\
\hline & & Post-op & 2.8 & 89.0 & 34.6 & 22.7 & 10.8 & 35.3 & 49.9 \\
\hline \multirow{8}{*}{ Moderate $(n=96)$} & \multirow{2}{*}{ EC } & Pre-op & 2.83 & 99.0 & 53.1 & 24.5 & 37.4 & 57.1 & 70.7 \\
\hline & & Post-op & 1.0 & 89.0 & 19.1 & 15.6 & 10.2 & 13.5 & 25.0 \\
\hline & \multirow{2}{*}{ BN } & Pre-op & 2.8 & 97.0 & 53.3 & 22.2 & 36.7 & 56.2 & 70.5 \\
\hline & & Post-op & 1.0 & 68.6 & 22.9 & 15.5 & 12.0 & 20.7 & 31.2 \\
\hline & \multirow{2}{*}{ RV } & Pre-op & 8.3 & 91.0 & 52.2 & 20.1 & 37.8 & 54.0 & 66.5 \\
\hline & & Post-op & 1.0 & 72.8 & 21.8 & 14.1 & 10.5 & 19.5 & 31.2 \\
\hline & \multirow{2}{*}{ AV } & Pre-op & 1.0 & 91.0 & 32.8 & 21.8 & 16.8 & 27.2 & 48.3 \\
\hline & & Post-op & 1.0 & 99.0 & 35.9 & 25.4 & 16.3 & 29.2 & 56.2 \\
\hline \multirow{8}{*}{$\begin{array}{l}\text { Severe- profound } \\
(n=72)\end{array}$} & \multirow{2}{*}{ EC } & Pre-op & 2.83 & 97.0 & 51.2 & 24.5 & 36.4 & 53.8 & 67.3 \\
\hline & & Post-op & 1.0 & 87.0 & 27.5 & 21.4 & 9.2 & 24.8 & 45.8 \\
\hline & \multirow{2}{*}{ BN } & Pre-op & 4.7 & 95.0 & 51.9 & 21.7 & 40.5 & 49.7 & 68.5 \\
\hline & & Post-op & 1.0 & 68.5 & 28.9 & 16.4 & 14.2 & 29.0 & 42.6 \\
\hline & \multirow{2}{*}{ RV } & Pre-op & 10.2 & 93.0 & 53.4 & 20.1 & 43.6 & 52.0 & 70.7 \\
\hline & & Post-op & 1.0 & 68.7 & 28.0 & 17.3 & 12.0 & 24.8 & 41.8 \\
\hline & \multirow{2}{*}{ AV } & Pre-op & 1.0 & 87.0 & 31.0 & 21.4 & 10.5 & 29.5 & 43.6 \\
\hline & & Post-op & 1.0 & 99.0 & 32.3 & 23.6 & 12.2 & 29.3 & 51.0 \\
\hline
\end{tabular}

Abbreviations: EC, ease of communication; BN, background noise; RV, reverberation; AV, aversiveness; Min, minimum; Max, maximum; $M$, mean; SD, standard deviation; Q1, first quartile; Me, median; Q3, third quartile

\section{Correlation between subjective and audiometric hearing outcomes}

In an attempt to determine if audiometric data can predict how a patient will perceive hearing change after surgery, we performed correlations in the group of 195 patients between changes after stapedotomy of $\mathrm{AC}$ and $\mathrm{BC}$ thresholds and ABG and change in APHAB Total score. There was a general trend indicating that the greater the improvement in audiometric data, the greater the reduction of hearing problems reported by the patient. However, the correlations were relatively weak. The correlation between change of AC threshold and change of APHAB Total scores was $r h o=0.23 ; p<0.01$. The correlation between change of size of ABG and change of APHAB Total score was $r h o=0.19 ; p<0.05$. There were no correlation between change of BC threshold and change of APHAB Total score $(r h o=0.07 ; p>0.05)$.

\section{Discussion}

In the hands of an experienced surgeon, stapes surgery provides successful closure of the ABG in most cases (8). Yung and Oates, who examined the learning curve for stapes surgery and the implication for surgical training, concluded that surgeons and clinics which report large numbers of stapes surgeries achieved better hearing results and fewer complications (22). On the basis of our results, we have found that the average $\mathrm{AC}$ and $\mathrm{BC}$ thresholds and the $A B G$ are improved by stapedotomy, which corresponds to previously reported results in the literature $(5,8,23)$.

Analysis of the APHAB results showed that the smallest hearing problems were reported in the group of patients with slight hearing impairment. Because most of them had normal BC thresholds, these patients were most likely to achieve a normal level of hearing after surgery. Although the greatest improvement in AC thresholds and $A B G$ was obtained in the severe-profound hearing impaired group, the subjective benefits reported by patients were less than the moderately hearing impaired group. We therefore speculate that there is a direct link between preoperative BC thresholds and the patient's postoperative perception of hearing benefit. In patients with severe-profound hearing impairment, preoperative $\mathrm{BC}$ thresholds were worse by an average of $15 \mathrm{~dB}$ compared to patients with moderate hearing impairment. 
Even though stapedotomy was generally successful (closure of the $A B G$ ), the majority of these patients had a moderate hearing loss, insufficient to provide functional hearing, which might also explain the subjective perception of their disability. In these patients, complementary amplification may involve conventional hearing aids, active middle ear implants, bone-conducted devices, or direct stimulation of the inner ear with a CODACS-type implant (24).

Meyer at al., in a group of 29 patients who had undergone stapedectomy, also reported a weak correlation between subjective patient hearing and audiometric results (16). The authors suggest that the difference between a patient's actual hearing impairment and their disability and handicap are highly individual, and depend on behavioural and psychosocial factors. Tan et al., assessing sound quality after stapedotomy using the APOSE questionnaire (the Amsterdam Post-Operative Sound Evaluation), concluded that the postoperative audiometric results did not always correspond to the perceived quality of sound (17). On the other hand, studies by Lailach et al. and Chandarana et al. demonstrated a positive correlation between postoperative ratings of the subjective hearing measurement by HHI (the Hearing Handicap Inventory) and audiometric data $(9,25)$. Lundman et al. conducted a retrospective hearing assessment in a group of 95 patients with otosclerosis 3 to 8 years after stapedectomy (18); interestingly, despite acceptable surgical results (closure of the ABG within $20 \mathrm{~dB}$ ), in $95 \%$ of patients only $64 \%$ had satisfactory social hearing (normal or slight hearing disability at work or in social life) at follow-up. The authors explained the above results in terms of the progression of otosclerosis, which often causes a worsening of hearing thresholds on both sides. The progressive nature of otosclerosis has been addressed in the literature. Topsakal et al., based on 1064 audiograms, looked at the audiological progression of otosclerosis (26). Multiple linear regression analysis showed that the average rate of threshold deterioration for $\mathrm{AC}$ was $0.45 \mathrm{~dB} / \mathrm{yr}$ while the annual threshold deterioration for $\mathrm{BC}$ was $0.37 \mathrm{~dB} / \mathrm{yr}$.

There are various theories to explain why patients' self-reported hearing outcomes provide information that is rather different from the audiometric data. According to Subramaniam et al., who assessed the subjective hearing of patients undergoing unilateral stapedotomy, hearing in the non-operated ear should also be considered (27). If there are asymmetric hearing levels, and the non-operated ear has better hearing, then patients may still not sense any benefit from surgery despite an improvement in hearing thresholds in the operated ear.

From the patient's point of view, the preoperative state of affairs seems to be the most important indicator for the outcome of surgical treatment. According Lundman et al. and Tan et al., patients should be informed about the degree of functional improvement that can be expected from closure of the ABG, as well as the risk of sound deterioration and hyperacusis $(17,18)$. The outcomes noted in the patient questionnaires also depend on the expectations of the patient. Strömbäck et al. suggest that patients with keen expectations might be disappointed, while the impressions from patients with lower expectations will be overly positive (5). According to Subramaniam et al., the time period over which the patient has experienced hearing loss can be important to the perception of a surgery's success. Patients with longstanding hearing loss have probably come to accept their impairment, and this is likely to moderate their expectations of the outcome of surgery (27). If so, then even a slight improvement in audiometric indicators can be well received by the patient when they find that surgery has increased their level of independence and communication competence. However, a patient with a recent history of hearing loss is unlikely to have yet accepted hearing impairment, and their expectations for restoration of hearing are subsequently higher, which in turn increases the risk of disappointment.

\section{Limitations of the study and future directions}

The limitations of this prospective study should be mentioned. We were unable to obtain postoperative pure-tone audiograms from all study participants. Some patients did not report for designated postoperative medical visits, mostly due to long distance from their place of residence. In these cases, the use of a self-reported questionnaire was intended to obtain the missing information about the effectiveness of stapes surgery. Looking at research groups in the studies analysed earlier, we note that not all patients gave postoperative observations, in particular long-term ones $(1,5,15,18)$.

Despite increased knowledge and techniques for stapes surgery, we still cannot completely stop progress of the disease $(4,6,28)$. Our prospective study used an interval shorter than 12 months for postoperative audiometry and self-assessment of hearing change. It should also be added that although the APHAB questionnaire is the most widely used hearing-specific questionnaire among Polish audiology patients, this tool is dedicated to assessing the effectiveness of hearing aids or hearing implants. This was the first attempt to assess subjective hearing in a group of patients undergoing stapedotomy due to otosclerosis in our center. Therefore, in future work it is worth considering the implementation of a new self-report tool in groups of otosclerosis patients.

\section{Conclusion}

The results of audiometric tests demonstrate the effectiveness of stapedotomy in improving the hearing of the majority of patients. However, audiometric results give limited information on the status of the patient's hearing. The patient's subjective perspective, together with audiometric data, provides valuable information that can be helpful in clinical decision-making and counselling.

\section{Conflicts of Interest and Source of Funding}

The authors disclose no conflicts of interest. No other benefits were received. 


\section{References}

1. Crompton M, Cadge BA, Ziff JL, et al. The epidemiology of otosclerosis in a British cohort. Otol Neurotol, 2018; 40: 22-30.

2. Skarżyński H, Gos E, Dziendziel B, Raj-Koziak D, Włodarczyk EA, Skarżyński PH. Clinically important change in tinnitus sensation after stapedotomy. Health Qual Life Outcomes, 2018; 16: 208.

3. Dziendziel B, Skarżyński PH, Rajchel J, Skarżyńska MB, Skarżyński $\mathrm{H}$. Evaluation of the prevalence and tinnitus distress in patients undergoing surgical treatment of otosclerosis: the overview. Now Audiofonol. 2017; 6: 13-20.

4. Redfors YD, Möller C. Otosclerosis: thirty-year follow-up after surgery. Ann Otol Rhinol Laryngol, 2011; 120: 608-14.

5. Strömbäck K, Lundman L, Bjorsne A, Grendin J, Stjernquist-Desatnik A, Dahlin-Redfors Y. Stapes surgery in Sweden: evaluation of a national-based register. Eur Arch Otorhinolaryngol, 2017; 274: 2421-7.

6. Ealy M, Smith RJH. Otosclerosis. Adv Otorhinolaryngol, 2011; 70: 122-9.

7. Salmon C, Barriat S, Lefebvre PP. Stapes surgery for otosclerosis in patients presenting with mixed hearing loss. Audiol Neurootol, 2018; 23: 82-8.

8. Maniu A, Cosgarea M. Technical and functional hearing results after unilateral stapes surgery for otosclerosis at Cluj-Napoca University Hospital. Eur Arch Otorhinolaryngol, 2013; 270: 2215-24.

9. Lailach S, Schenke T, Baumann I, et al. Living with otosclerosis: disease-specific health-related quality-of-life measurement in patients undergoing stapes surgery. Eur Arch Otorhinolaryngol, 2018; 275: 71-9.

10. Hallberg LRM, Hallberg U, Kramer SE. Self-reported hearing difficulties, communication strategies and psychological general well-being (quality of life) in patients with acquired hearing impairment. Disabil Rehabil, 2008; 30: 203-12.

11. Heffernan E, Habib A, Ferguson M. Evaluation of the psychometric properties of the social isolation measure (SIM) in adults with hearing loss. Int J Audiol, 2019; 58(1): 45-52.

12. Monzani D, Galeazzi G, Genovese E, Marrara A, Martini A. Psychological profile and social behaviour of working adults with mild or moderate hearing loss. Acta Otorhinolaryngol Ital, 2008; 28: 61-6.

13. Roup CM, Post E, Lewis J. Mild-gain hearing aids as a treatment for adults with self-reported hearing difficulties. J Am Acad Audiol, 2018; 29: 477-94.

14. Cox RM, Alexander GC, Gray GA. Audiometric correlates of the unaided APHAB. J Am Acad Audiol, 2003; 14: 361-71.
15. Hazenberg AJC, Minovi A, Dazert S, Hoppe FF. Predictors of listening capabilities and patient satisfaction after stapes surgery in otosclerosis. Otol Neurotol, 2013; 34: 220-6.

16. Meyer SE, Megerian CA. Patients' perceived outcomes after stapedectomy for otosclerosis. Ear Nose Throat J, 2000; 79: 846-8, 851-2, 854 passim.

17. Tan FML, Grolman W, Tange RA, Fokkens WJ. Quality of perceived sound after stapedotomy. Otolaryngol Head Neck Surg, 2007; 137: 443-9.

18. Lundman L, Mendel L, Bagger-Sjöbäck D, Rosenhall U. Hearing in patients operated unilaterally for otosclerosis. Self-assessment of hearing and audiometric results. Acta Otolaryngol, 1999; 119: 453-8.

19. World Health Organization. Prevention of blindness and deafness. Grades of hearing impairment [Internet]. Available from: https://www.schwerhoerigen-netz.de/fileadmin/user_upload/dsb/ Dokumente/Information/Politik_Recht/Hoergeraete/who-gradeshearing.pdf. Viewed 2019-03-18.

20. Cox RM, Alexander GC. The abbreviated profile of hearing aid benefit. Ear Hear, 1995; 16: 176-86.

21. Fackrell K, Hall D, Barry J, Hoare D. Tools for tinnitus measurement: development and validity of questionnaires to assess handicap and treatment effects. In: Tinnitus: Causes treatment and short and long-term health effects. New York: Nova Science Publishers; 2014, 13-60.

22. Yung MW, Oates J. The learning curve in stapes surgery and its implication for training. Adv Otorhinolaryngol, 2007; 65: 361-9.

23. Lancer H, Manickavasagam J, Zaman A, Lancer J. Stapes surgery: a national survey of British otologists. Eur Arch Otorhinolaryngol, 2016; 273: 371-9.

24. Skarżyński H. Surgical treatment of otosclerosis: expanding indications and new recommendations. J Hear Sci, 2018; 8(1): 9-12.

25. Chandarana S, Parnes L, Agrawal S, Fung K. Quality of life following small fenestra stapedotomy. Ann Otol Rhinol Laryngol, 2005; 114: 472-7.

26. Topsakal V, Fransen E, Schmerber S, et al. Audiometric analyses confirm a cochlear component, disproportional to age, in stapedial otosclerosis. Otol Neurotol, 2006; 27: 781-7.

27. Subramaniam K, Eikelboom RH, Marino R, Atlas MD, Rajan GP. Patient's quality of life and hearing outcomes after stapes surgery. Clin Otolaryngol, 2006; 31: 273-9.

28. Redfors YD, Hellgren J, Möller C. Hearing-aid use and benefit: a long-term follow-up in patients undergoing surgery for otosclerosis. Int J Audiol, 2013; 52: 194-9. 